Document downloaded from:

http://hdl.handle.net/10251/101710

This paper must be cited as:

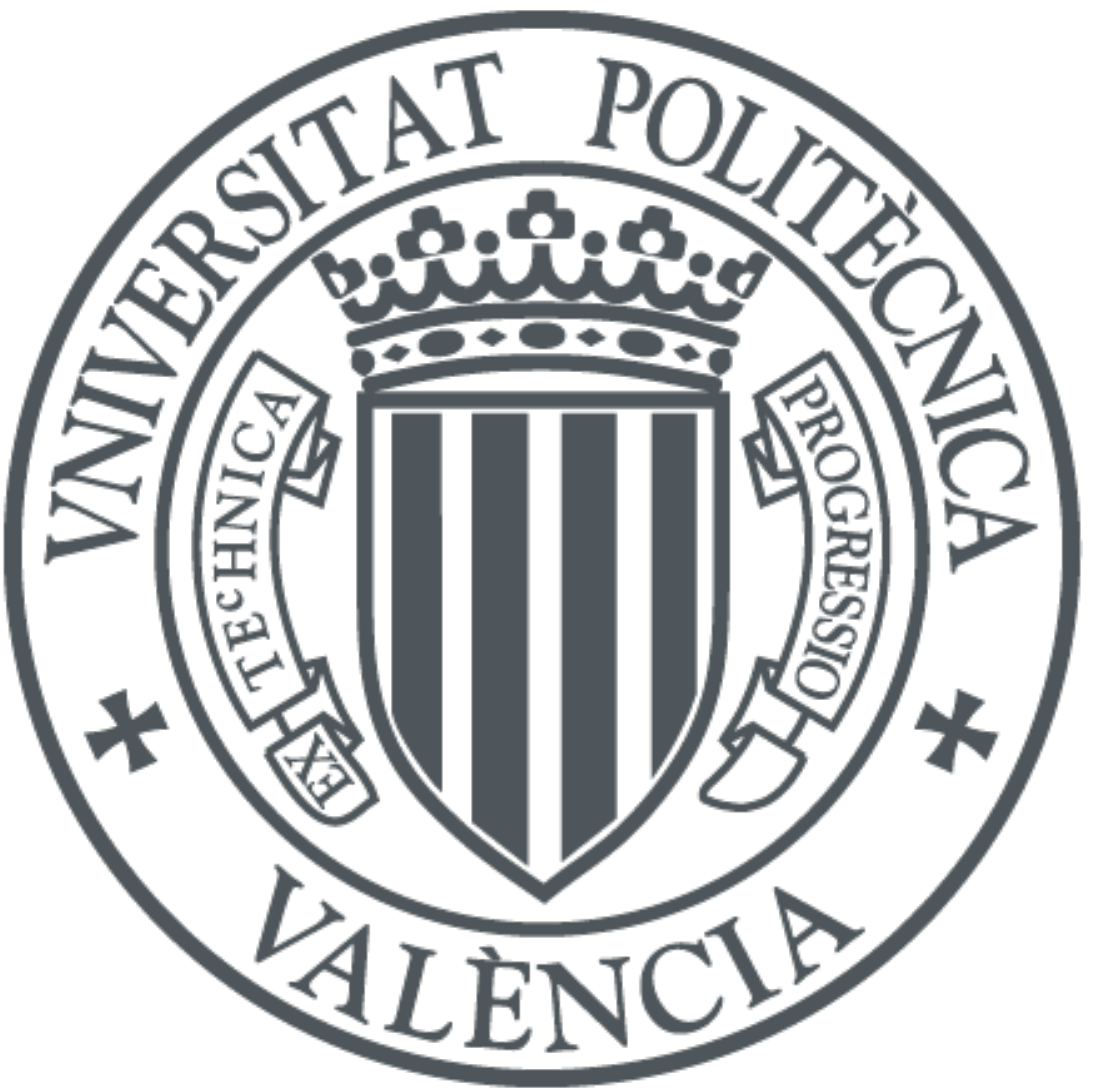

The final publication is available at

https://doi.org/10.1016/j.scitotenv.2017.05.259

Copyright Elsevier

Additional Information 


\title{
Linking Pan-European data to the local scale for decision making for global change and water scarcity within water resources planning and management
}

\author{
Sara Suárez-Almiñana ${ }^{1}$, María Pedro-Monzonís ${ }^{1}$, Javier Paredes-Arquiola ${ }^{1}$, Joaquín \\ Andreu $^{1}$ and Abel Solera ${ }^{1}$ \\ ${ }^{1}$ Research Institute of Water and Environmental Engineering (IIAMA), Universitat Politècnica de València, \\ Valencia (Spain) \\ *sasual@upv.es
}

\begin{abstract}
This study focuses on a novel type of methodology which connects Pan-European data to the local scale in the field of water resources management. This methodology is proposed to improve and facilitate the decision making within the planning and management of water resources, taking into account climate change and its expected impacts. Our main point of interest is focused on the assessment of the predictability of extreme events and their possible effects, specifically droughts and water scarcity. Consequently, the Júcar River Basin was selected as the case study, due to the ongoing water scarcity problems and the last drought episodes suffered in the Mediterranean region.

In order to study these possible impacts, we developed a modeling chain divided into four steps, they are: i) data collection, ii) analysis of available data, iii) models calibration and iv) climate impact analysis. Over previous steps, we used climate data from 15 different regional climate models (RCM) belonging to the three different Representative Climate Pathways (RCP) coming from a hydrological model across all of Europe called E-HYPE. The data were bias corrected and used to obtain statistical results of the availability of water resources for the future (horizon 2039) and in form of indicators. This was performed through a hydrological (EVALHID), stochastic (MASHWIN) and risk management (SIMRISK) models, all of which were specifically calibrated for this basin.

The results show that the availability of water resources is much more enthusiastic than in the current situation, indicating the possibility that climate change, which was predicted to occur in the future has already happened in the Júcar River Basin. It seems that the so called "Effect 80", an important decrease in water resources for the last three decades, is not well contemplated in the initial data.
\end{abstract}

Keywords: climate services, Júcar River Basin, climate change, Pan-European data, AQUATOOL DSSS

\section{Introduction}

Climate change is a natural process that has been accelerated by human influence, due to the huge amount of emissions of greenhouse gases into the atmosphere. It is related to human development, growth and consumption patterns (Vargas-Amelin and Pindado, 2014), and currently these emissions 
are the highest in history (IPCC, 2014). However, it is not the only factor that contributes to climate change, as could volcanic activity and ocean circulation also be contributors, however burning fossil fuels and industrial processes have been recognised by scientific communities as the main contributors that have increased the concentration of $\mathrm{CO}_{2}$ in the atmosphere (IPCC, 2014), consequently these factors could be the main contributors that are responsible for the increase of the Earth's temperature.

In addition, it is known that the Mediterranean area is becoming drier, and therefore more vulnerable to wildfires and drought. There is an elevated probability that Mediterranean river basins, as many other semi-arid regions, will suffer an important decline in water resources availability attributable to climate change (Vargas-Amelin and Pindado, 2014). In the coming years, it is expected that the increasing water demand in combination with water scarcity due to climate change will intensify the current water stress.

Many studies suggest that climate change will amplify the frequency of current problems (Bates et al., 2008), and within Europe, Spain is one of the most exposed countries to climate change, caused by its socio-economic and geographic features (MMA, 2005). Moreover, the general pattern of the projected models indicate a decrease in precipitation and an increase in temperature for this area (Estrela et al., 2012; Garrote, 2009), within its limitations regarding the uncertainty, the spatial resolution, the projections range and their complexity among others. This could lead to an intense competition between different user groups and sectors due to the possible prolonged periods of water scarcity where water is already limited today (van Vliet et al., 2015), all related to social, economic and environmental impacts. Thus, it seems clear that the adaptation to climate change necessarily implies the participation of scientists, governments and society.

In this sense, the European Union (EU) Roadmap on climate services (European Commission, 2015) represents the convergence between society's actionable research and the faculty of the climate research community to support personalized knowledge, information and data (van den Hurk et al., 2016). Therefore, if society is aware of the existence of a reliable forecast, then the anticipation for extreme events could become a very operative adaptation measure (van den Hurk et al., 2016).

Knowing all this, a new methodology based on a modeling chain (hydrological, stochastic and management models) is presented in this paper with the aim of creating a link between climate services and decision-making in water resources planning and management at the river basin scale. It is based on the application of a decision support system, in order to support adaptation, mitigation and reduce risk disasters. To accomplish with this objective, the assessment of the effects of global 
change in the Júcar River Basin (east of Spain) was performed to evaluate if current urban and agricultural requirements could be suitably met under future changing scenarios.

This process begins with Pan-European climatic data from the E-HYPE hydrological model belonging to the SWICCA Copernicus Project (Service for Water Indicators in Climate Change Adaptation). This projects aim is to bridge the gap between institutes who provide climate-impact data on one side, and water managers and policy makers on the other. As several authors have highlighted (Donnelly et al., 2016), the E-HYPE model presents some inconveniences in the Mediterranean area, presenting some gaps in evapotranspiration, aquifers and water extraction among others (Donnelly et al., 2016). Thus, it was necessary to correct climate data and use a modeling chain specifically calibrated for this area. The importance of this is to obtain reliable results that should be able to detect future periods of drought and avoid the possible impacts associated with them. In this sense, it could be possible to know of droughts in advance and make the right decisions by preventing impacts to water resources availability in the future. In addition, it could be incorporated to other countries or river basins affected by water scarcity into water planning.

\section{Materials and methods}

The methodology presented in Figure 1 was developed to connect Pan-European data to the local scale in order to assess the state of the system and to propose the measures required in future periods, taking into account the impacts of water scarcity due to global warming. It is represented by two pathways (depending on the origin of the data), which interact with one another and finally converge in a final step. 


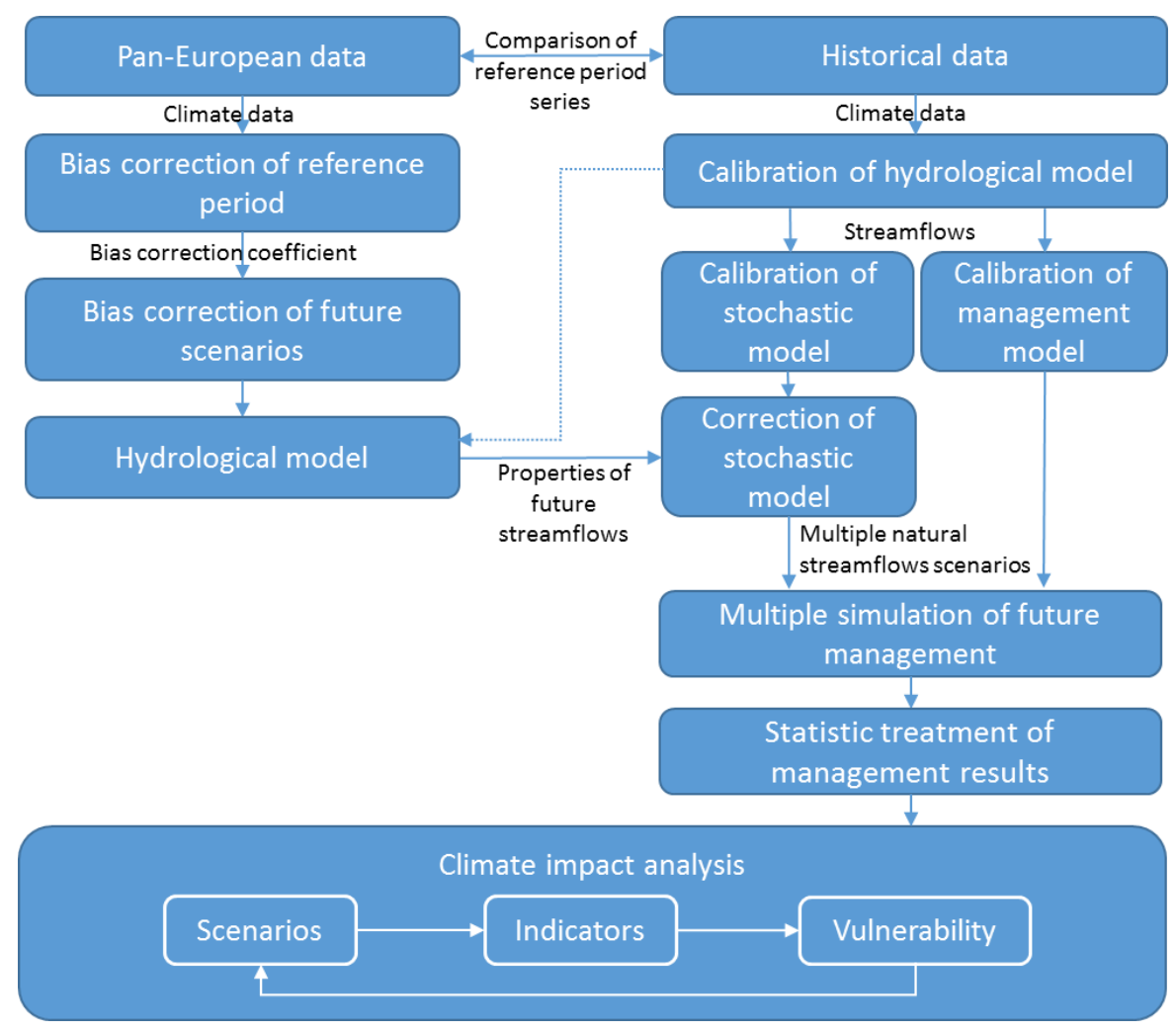

Figure 1. Methodology scheme for climate impact analysis in water resources planning and management

Pan-European and historical data collection are the first step of the methodology. Once data series' are obtained, a reference period is selected and both data are compared to know the accuracy of the forecast and to obtain a bias correction coefficient for correcting future scenarios. On the other hand, historical data are also used for model calibration. Firstly, the stochastic model is employed to generate multiple streamflow series equiprobable with the historical ones. Secondly, the previous generated series' are used to analyze multiple runs of the water management model, obtaining multiple different management results. Both ways are related for the correction of the stochastic model, which is done with the properties of corrected future scenarios. Finally, the climate impact analysis is performed for different regional climate models (RCM) in order to obtain several indicators and asses the vulnerability of the system, with the aim of applying some adaptation measures and mitigate the impacts of climate change. The application of these measures can be considered as a new scenario, because of that, the final step is a close-loop process. This procedure is explained below in more detail, it is divided in several steps, which are: 1- Data collection; 2- Analysis of the available data; 3- Models calibration; 4- Climate impact analysis. 
Step 1: Data collection - The data required come from Pan-European and local databases, it includes: river flows, precipitation, potential evapotranspiration and temperature (minimum, average and maximum).

Pan-European data come from the SWICCA Copernicus project, which has developed a website that enables the download of climate, hydrological and indicators data from all over Europe (http://swicca.climate.copernicus.eu/) at different space and time resolutions. In this sense, based on the most appropriate space resolution for this research (catchment resolution, $215 \mathrm{~km}^{2}$ ), data from the E-HYPE hydrological model (Hundecha et al., 2016) were used. E-HYPE uses global databases and Global Monitoring for the Environment and Security (GMES) satellite products as input data and then is forced by the European Centre for Medium-Range Weather Forecasts (ECMWF) and the Swedish Meteorological and Hydrological Institute (SMHI) to calculate the water balance, hydrological variables and daily discharge for the entire continent (Hundecha et al., 2016). Some of the uses of this model are hydrological forecasts, water allocation, predictions for ungauged basins, climate change impact assessments and hydraulic flood models.

Therefore, we disposed the daily time series of precipitation, temperature and river flows from the period of 1971-2100 (using the years 1971-2000 as a reference period) and for 11 different RCMs, belonging to the three Representative Concentration Pathways (RCP) (2.6 mitigation, 4.5 stabilization and 8.5 high greenhouse gas scenarios). In Table 1, the different ensembles and their origin (Global Climate Model and Institute) are presented. On the other hand, historical data come from the Spain02 database (Herrera et al., 2012), conformed by an observations grid of approximately $20 \mathrm{~km}$ of spatial resolution for the period 1950-2003. Thus, we dispose data from the same reference period on which we are going to analyze on both E-HYPE model, as well as Spain02, from 1971 to 2000.

\begin{tabular}{|c|c|c|c|c|}
\hline \multicolumn{5}{|c|}{ Model input/forcing } \\
\hline $\mathbf{R}$ RCP & GCM & RCM & Period & Institute \\
\hline \multirow{2}{*}{$\mathbf{2 . 6}$} & EC-EARTH & RCA4 & $1970-2100$ & SMHI \\
\cline { 2 - 5 } & MPI-ESM-LR & REMO2009 & $1951-2100$ & CSC \\
\hline \multirow{4}{*}{} & EC-EARTH & RCA4 & $1970-2100$ & SMHI \\
\cline { 2 - 5 } & EC-EARTH & RACMO22E & $1951-2100$ & KNMI \\
\cline { 2 - 5 } & HadGEM2-ES & RCA4 & $1970-2098$ & SMHI \\
\cline { 2 - 5 } & MPI-ESM-LR & REMO2009 & $1951-2100$ & CSC \\
\cline { 2 - 5 } & CM5A & WRF33 & $1971-2100$ & IPSL \\
\hline \multirow{2}{*}{$\mathbf{8 . 5}$} & EC-EARTH & RCA4 & $1970-2100$ & SMHI \\
\cline { 2 - 5 } & EC-EARTH & RACMO22E & $1951-2100$ & KNMI \\
\cline { 2 - 5 } & HadGEM2-ES & RCA4 & $1970-2098$ & SMHI \\
\hline
\end{tabular}




\begin{tabular}{|c|c|c|c|}
\hline MPI-ESM-LR & REMO2009 & $1951-2100$ & CSC \\
\hline $\begin{array}{l}\text { Table 1. Characteristics of the 11 Regional Climate Model data provided by E-HYPE hydrological model. (Modified from: } \\
\text { http://swicca.climate.copernicus.eu/wp-content/uploads/2016/10/Metadata_Precipitation_catchment.pdf) }\end{array}$
\end{tabular}

Step 2: Analysis of the available data - In this step the comparison between both data, Pan-European and historical is performed, in order to know the accuracy of the forecast in the reference period (1971-2000) and to apply a bias correction for the entire period (1971-2100) in case their differences are notable. Two types of comparisons were performed, firstly, with river flows from the same points, coinciding with the main sub-basins of the system, where the main reservoirs are placed. Secondly, the comparison was done with climate data, comparing the 11 RCMs with historical data and extracting a bias correction coefficient based on the differences between historical data and an average of all RCMs. With these corrected data, it is possible to extract river flows with a hydrological model to feed other models that reveal the performance of the system.

Step 3: Models calibration - In this section historical data are employed to calibrate a hydrological model for the case study, and then, its outputs, as natural river flows, are used for the calibration of stochastic and management models.

The stochastic model was corrected with the properties, the mean in this case, of bias corrected future period series of river flows from step 2. It is used to generate multiple synthetic series' of river flows for different future scenarios. On the other hand, the historical outputs of the hydrological model are utilized as inputs for the calibration of the management model, where all important elements of the Júcar River water allocation system are incorporated.

In the specific case of the groundwater modeling, there are two types of aquifers, the most important is a multicellular aquifer (La Mancha Oriental aquifer) whose relationship with the surface system depends on a law represented by different discharge coefficients identified as cells, which would be two in this case. The other is a single cell-aquifer whose relationship with the surface system is such that the surface system receives the drainage from the aquifer, normally in the form of a spring. These were calibrated with a contrast of the outputs to the river and the gauging balance.

Regarding the models validation, the hydrological model was validated with the streamflows series of several years coming from gauging stations from non-altered areas. The management model was validated by the River Basin Agency with gauging data specified in the Júcar River Basin Management Plan (Annex 6). 
Step 4: Climate impact simulation - At this step, multiple runs of the water management model are performed. This model provides information about the evolution of water supplies considering different scenarios. In this final step, the climate impact analysis is performed as a closed-loop process, this means using the new scenarios, where an adaptation measures has been applied, and verifying if those measures could be effective or not through the evaluation of this indicator.

The methodology can be followed using different methods and models. We used the AQUATOOL Decision Support System Shell (DSSS) (Andreu et al., 1996) and its associated modules which are described below. AQUATOOL DSSS is user-friendly for water resources planning and management and is used at a national and international level. This software has been evolving over time to cover the major problems related to water management and facilitate the related work in the same tool. Thus, it has integrated several modules related to the assessment of water resources through rainfall-runoff modeling, the simulation and optimization of basin management and water quality modeling, among others.

The EVALHID module (Paredes-Arquiola et al., 2012) is used to develop a hydrological model in complex basins and its main goal is to evaluate the amount of water resources generated in each basin. This module has integrated several rainfall-runoff models and all of them have been aggregated with semi distributed applications at the sub-basin scale. They can be chosen depending on the available data, the complexity of the basin and the users experience in the development and calibration of hydrological models.

The SIMRISK module (Sánchez-Quispe et al., 2001) evaluates the management risks in the short, medium and long-term for a certain river basin. The process used is based on the Monte-Carlo method. It consists of generating multiple, future and equiprobable natural streamflow scenarios, and simulating the management of the system according to the criteria defined previously for each scenario. Each simulation will provide different results, which are statistically treated in order to obtain the probable estimation of the final situation of the system at the end of the present campaign, or after two or more hydrological years.

The MASHWIN module (http://www.upv.es/aquatool/es/index es.html) is used to analyze the historical hydrological inflow series and the formulation of stochastic models for generating synthetic series. Its principal utility is to complement the SIMRISK module, generating the different scenario series of future hydrological inflows. 


\section{Case study: The Júcar River Basin}

\subsection{Description of the basin}

The Júcar River Basin is one of the nine water exploitation systems of the Júcar River Basin District, which is placed in the East of the Iberian Peninsula (Figure 2) and flows into the Mediterranean Sea. In this district, the Júcar River Basin is the main water exploitation system due to its extension $\left(22,186.61 \mathrm{~km}^{2}\right)$ and the volume of water resources $\left(1,605.4 \mathrm{hm}^{3} /\right.$ year). Its drainage area belongs to the provinces of Cuenca, Teruel, Albacete and Valencia.
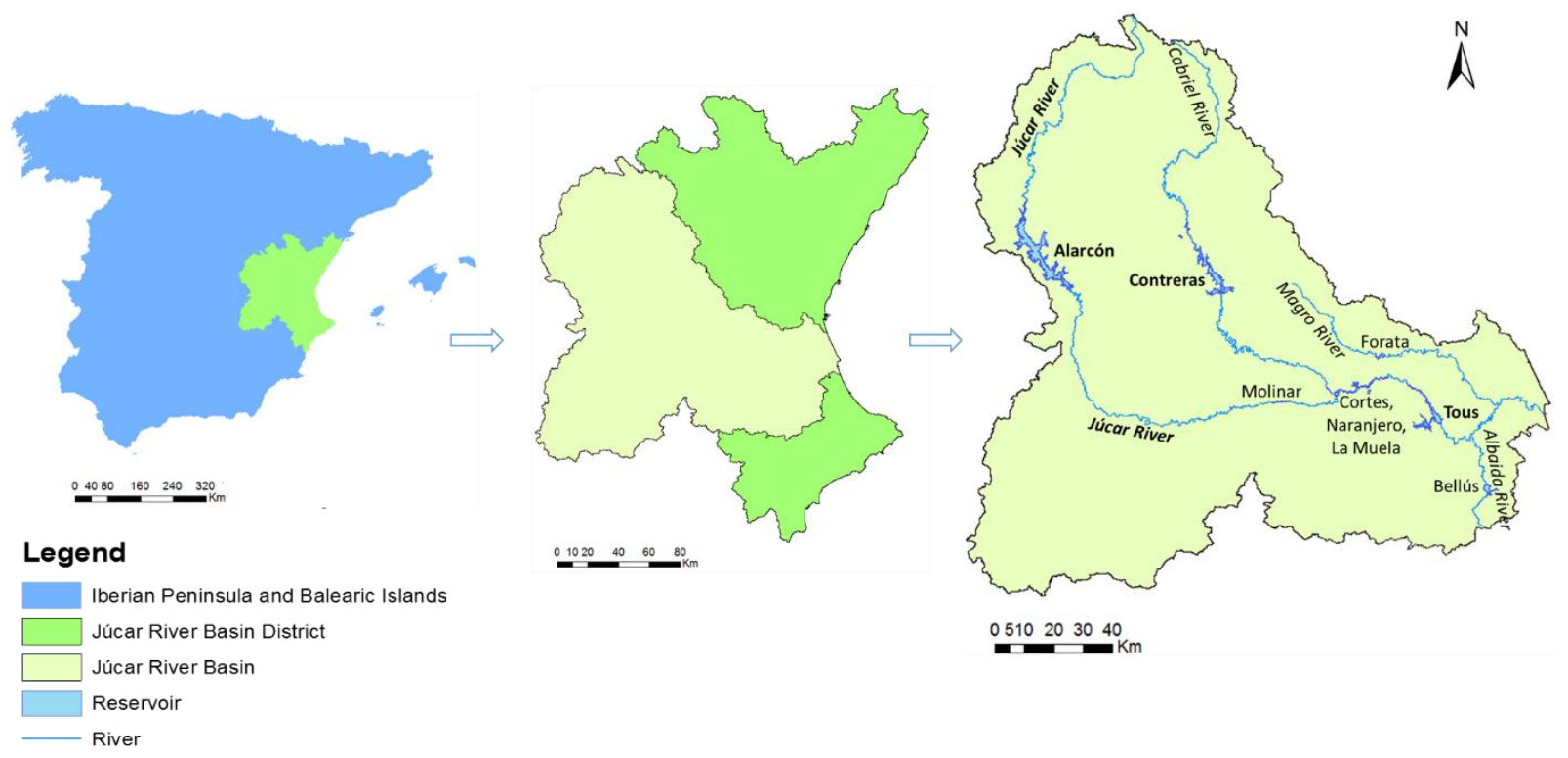

Figure 2. Location of the Júcar River Basin in the Iberian Peninsula

In the inland part of this basin (north) is the mountainous area of the lberic System, which works as a barrier for maritime fronts that force wet clouds to reach higher atmospheric layers and therefore, leave rainfall in this mountainous region. The coastal plain is formed by alluvial materials from the Neogene, where the nutrients of the soil support the major part of the irrigated agricultural production. Then, La Mancha (south west of the basin) is an area between the Iberic and Betic mountainous systems, characterized by a plain surface with an average altitude of $650 \mathrm{~m}$.

In addition, the formation of wetlands is another important feature of this basin. These wetlands are included in the RAMSAR international list and are fed from groundwater and from superficial runoff (in minor quantity). The most important wetland is La Albufera de Valencia, placed in the costal part of the basin with an area of 21.120 hectare, which is also composed of a vast extension of rice crops and a shoal that separates the lake to the Mediterranean Sea. 
Moreover, the major part of this area is covered by permeable materials that facilitate the rainfall infiltration to the underground, for example, the formation of karst by dissolution processes, resulting in interconnected cavities and fractures originated in rocks like limestone and dolomites.

This area has a typical Mediterranean climate, which is characterized by warm summers and mild winters, with an average precipitation of $475.2 \mathrm{~mm} /$ year and a potential evapotranspiration of 926.6 $\mathrm{mm} /$ year. The annual average temperatures are about 14 and $16.5 \stackrel{\circ}{\circ}$, where maximum degrees are reached during the months of July and August (dry season). In addition, during the months of October and November the phenomenon called "gota fría", a cold front with intense and short term precipitations may occur.

This basin owes its name to Júcar River, it is $512 \mathrm{~km}$ long and its main tributaries are the Cabriel, Albaida and Magro rivers. The hydrology is marked by the features of the Mediterranean climate, as can be the semi-aridity and the low precipitation rate mentioned before, which in combination with punctual torrential rains lead to floods and summer scarcity, resulting in a high seasonality and recurrent multiannual droughts.

The main reservoirs in the river basin are the Alarcón, Contreras and Tous dams, which jointly with groundwater aquifer, supply many different uses dominated by urban and agricultural demands, estimated at $203.37 \mathrm{hm}^{3} /$ year and 1,397.67 hm³/year (Confederación Hidrográfica del Júcar, 2015), respectively. The irrigated area covers 210,638 ha, which represents $54 \%$ of the whole district, note that the irrigation requirements do not coincide with the rainy season. Consequently, this is an adjusted system with an important relation between groundwater and surface resources. The relationship between water demands and water resources shows an indicator of water stress with a ratio of about $84 \%$, which means there is high scarcity and exploitation of the system. Due to the adjusted balance between water resources and demands, some measures were suggested and implemented, such as the reuse of sewage water, which is about $18.28 \mathrm{hm}^{3} / y e a r$ and it is expected to be higher in the coming years.

\subsection{Modeling the Júcar River Basin by using AQUATOOL DSS}

The methodology proposed in section 2 was applied to the Júcar River Basin, which was divided into five sub-basins, which are:

- Alarcón: This sub-basin covers the head of the Júcar River, which lies in the Montes Universales, to the Alarcón reservoir. 
- Alarcón - Molinar: This area covers the intermediate river basin of the Júcar River between the Alarcón and El Molinar reservoirs.

- Contreras: This area covers the catchment area of the Cabriel River, upstream of the Contreras reservoir.

- Tous: This area covers the intermediate river basin of the Júcar River between El Molinar, Contreras, and Tous reservoirs.

- Sueca: This area covers downstream of the Tous reservoir to the Huerto Mulet gauging station.

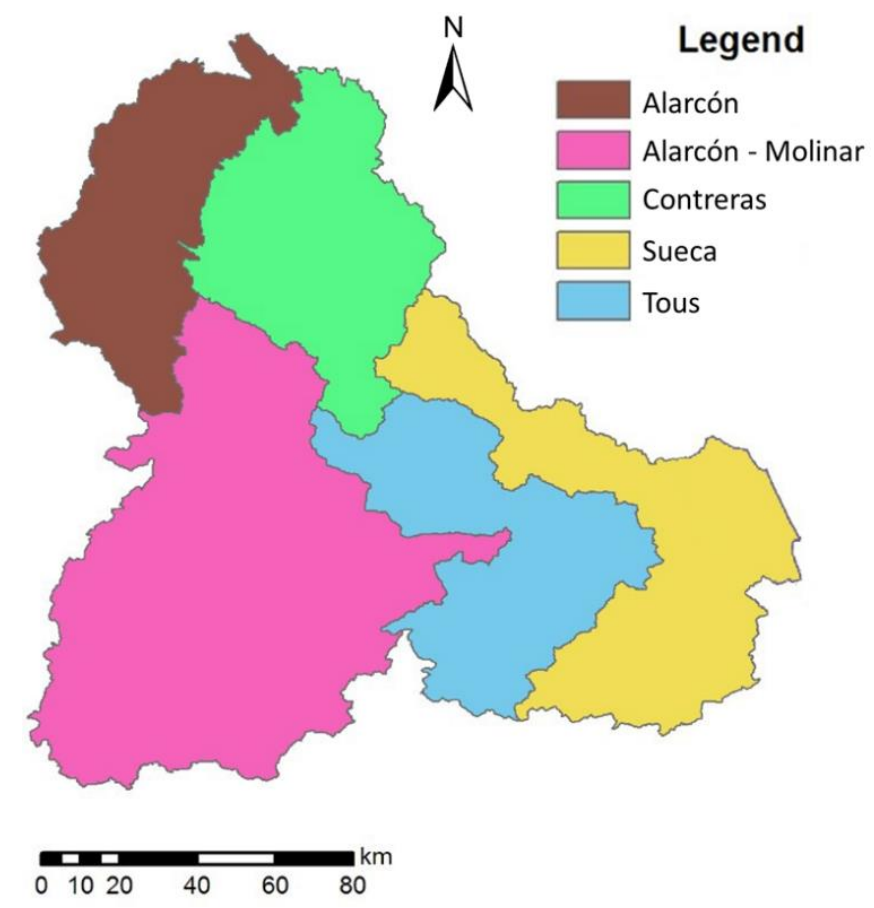

Figure 3. Sub-basins considered for modeling the Júcar River Basin

These sub-basins were employed in the hydrological model of the Júcar River Basin developed with EVALHID (Merino, 2012). Among the several rainfall-runoff models included in EVALHID, the HBV model (Hydrologiska Byråns Vattenbalans-avdelning) (Bergström and Forsman, 1973) was selected due to its versatility and the obtained results in comparison with other models in the case study. This model was performed with historical data of precipitation and temperature daily time series from the Spain02 database (Herrera et al., 2012) during the reference period of 1971-2000, which is characterized by a spatial resolution of $20 \mathrm{~km}$. Potential evapotranspiration (PET) was calculated by the Hargreaves method (Hargreaves and Samani, 1985).

Based on Pan-European temperature and precipitation data provided by the E-HYPE model (Hundecha et al., 2016) described in the materials and methods section (Table 1), bias correction was applied to the ensemble scenario composed of the monthly average values of temperature and precipitation in 
each of the five sub-basins considered for the reference period (1971-2000) (Figure 3). This decision was justified by two reasons; firstly, the results of applying the bias correction for each future scenario considered separately were analogous in each sub-basin, and secondly, the use of an ensemble scenario reduces the number of parameters. The values of precipitation and temperature accepted as historical data in the reference period come from the Spain02 database (Herrera et al., 2012), which has been employed in the formulation of water balances in other similar works (Pedro-Monzonís et al., 2016). Once temperature and precipitation data were bias corrected, they were used in the hydrological model developed with EVALHID. Therefore, 11 time series results of river flows were obtained for each of the future climate scenarios considered in Table 1. These series' were simulated at the daily scale and then they were accumulated to the monthly scale for the next step.

On the other hand, a multivariate ARMA $(1,0)$ monthly model (Salas et al., 1980) was adjusted using the historical monthly streamflow time series from 1980 to 2012, the period which is considered valid for basin planning. This model enables the generation of multiple equiprobable time series of river flows. According to the proposed methodology, 1,000 streamflow data series' were generated for each of the future scenarios considered. However, it has been observed that within future climate scenarios, the average of the river flows time series is changing during the years, specifically, the more pessimistic the greenhouse gas scenario is the greater reduction in river flows are over the years. Considering this fact and taking into account that this analysis is focused on water planning, instead of maintaining the historical average values of the river flows for the generated series, the average value considered was the average value of the climate scenarios on dates close to the planning horizon (2039). In this way, the model calibrated with historical streamflows data in natural regime has been altered in its parameters of the monthly average replacing them with those obtained from the selected future horizon (2039). Thus, 1,000 streamflow data series' were generated with 30 years length. The initial month of the analysis was October, which corresponds to the beginning of the hydrological cycle in the northern hemisphere. 30 years length is justified because the analyzed period must be as long as the reference period in order to allow comparisons.

The following step corresponds to the water management simulation model. It was built using the SIMGES module (Andreu et al., 1996), which is part of AQUATOOL DSSS, and the calibration was performed by using historical river flows for the period of 1980-2012. Figure 4 shows a representation of the Júcar Water Exploitation System with the main elements. This model was validated with observed data and it is a simplification of the model employed by the Júcar River Basin Agency (CHJ). As it is presented, the supplies of the main urban and irrigation demands proceed from both surface and groundwater resources. The main regulation reservoirs are the Alarcón, Contreras and Tous, which provide both a flood abatement capacity and the supply for water demands. Also included are 
a system of reservoirs (Molinar, Cortes, Naranjero and La Muela), which have great importance for hydropower generation (Solera et al., in press). The main aquifers are La Mancha Oriental and La Plana de Valencia, that are exploited for water supply.

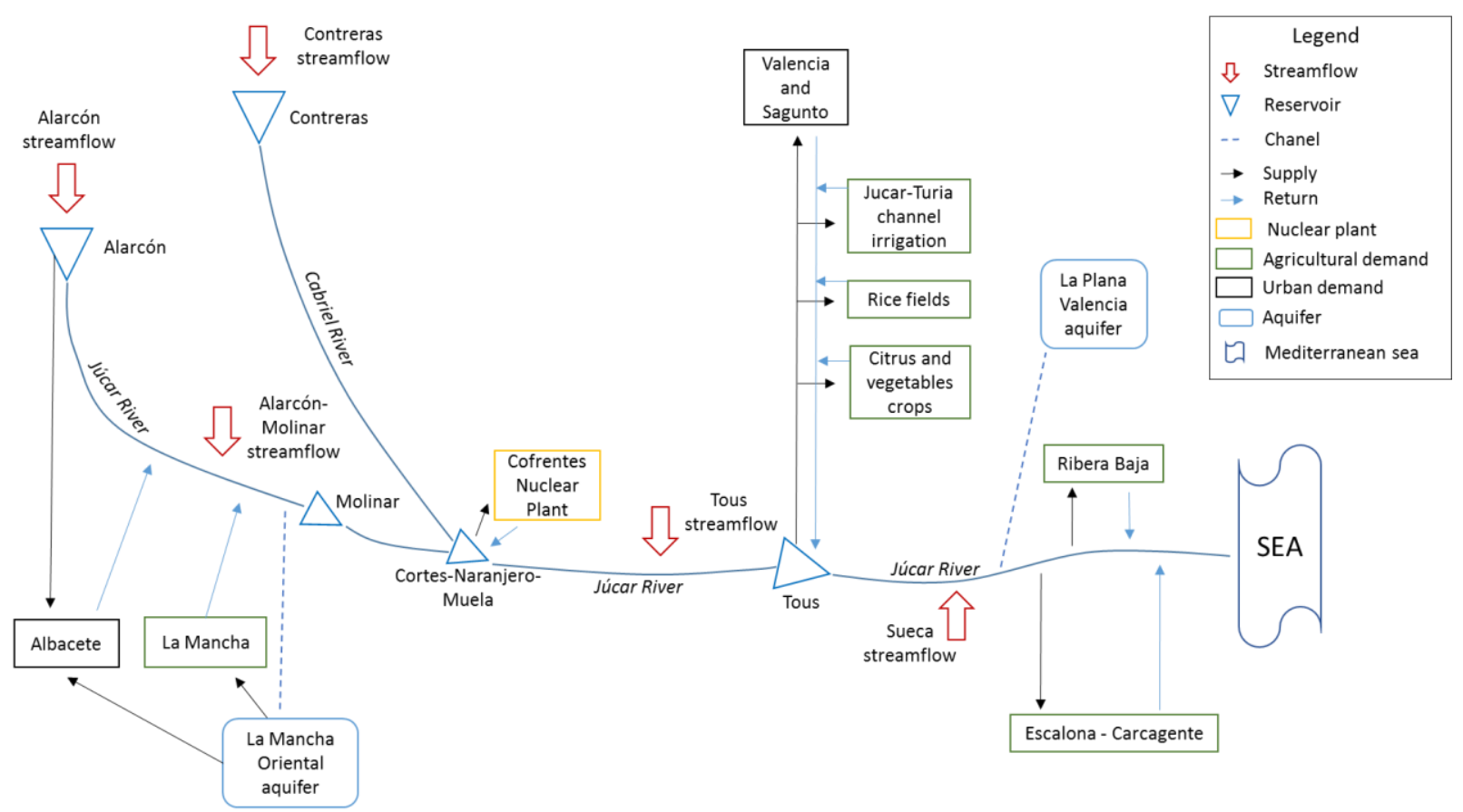

Figure 4. Scheme of the Júcar Exploitation System with the most relevant elements included in the simulation model

Developing a water management model is a requirement before applying the SIMRISK approach. In this sense, the simulation of the generated series is performed by the SIMRISK module in order to analyze the climate change impacts on the case study for future periods. This model enables decision makers to know the probability of supply failures as it includes the estimation of the performance of the water resources system, in addition to know the evolution of water supplies and water reserves. Thus, these statistical results enable the assessment of the vulnerability of the case study by employing the volume of water stored in the main reservoirs of the system as an indicator for the adaptation to climate change. In other words, climate change predictions allow decision makers to adopt the required measures in order to reduce the vulnerability of the system. 


\section{Results}

\subsection{Precipitation bias correction results and PET estimation}

Firstly, a comparison between the precipitation values provided by Pan-European data and the historical ones from the reference period is necessary to verify the consistency and reliability of the data. This assessment was done for the five sub-basins defined in section 3.2 and it is presented in Figure 5. In order to remove possible errors from the climate models, a bias correction was applied to transform Pan-European data into more similar observations. This bias correction was based on a monthly rate resulting from the differences between both averages for each month. The comparison of precipitation for the reference period showed an underestimation mainly in the winter months. 

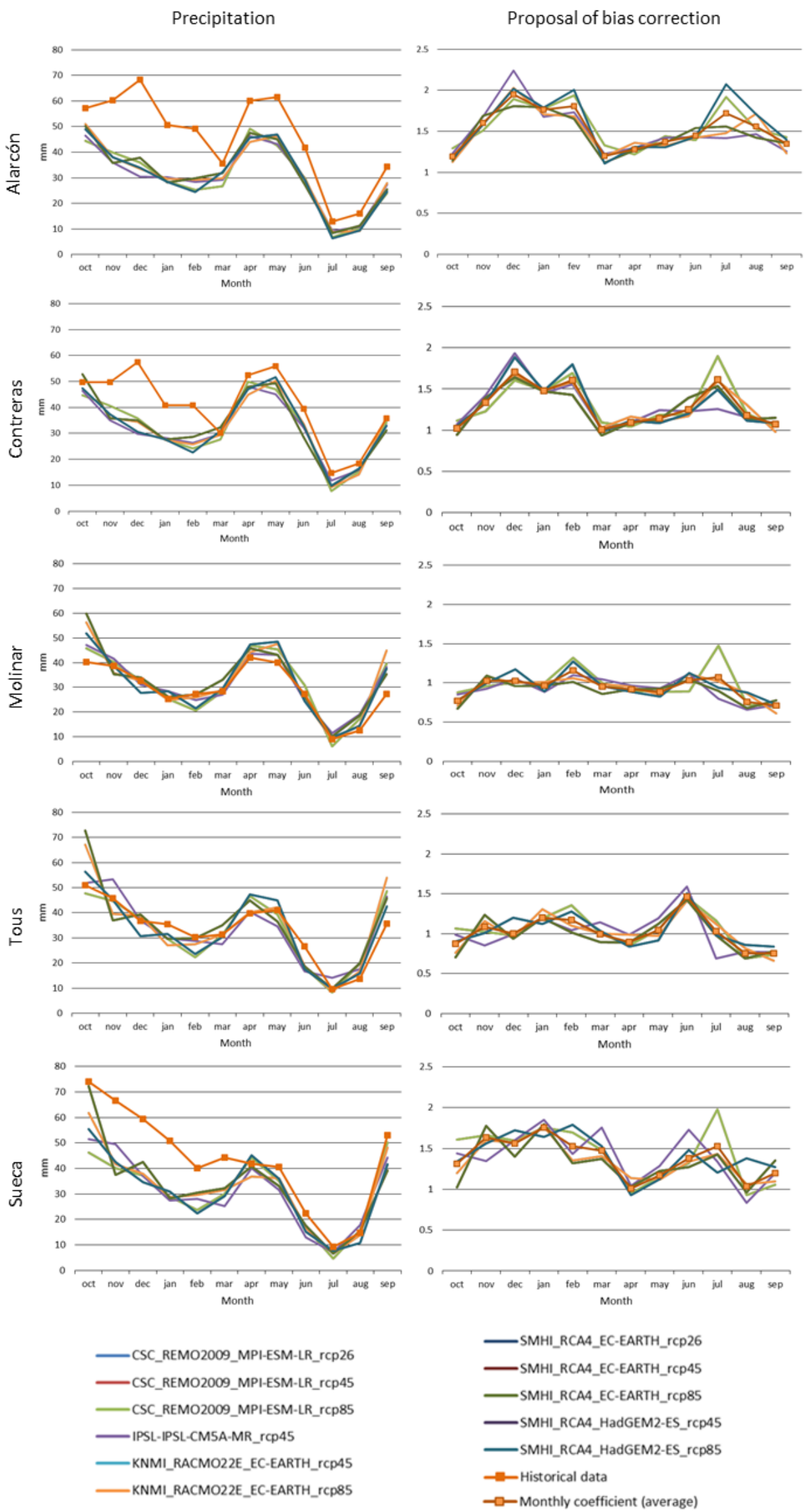

Figure 5. Precipitation, proposal of bias correction for each of the five sub-basins included in the hydrological model 
Similarly, for obtaining the PET, the Hargreaves method (Hargreaves and Samani, 1985) was applied by using historical data. This formula requires average, maximum and minimum temperature (Tmean, Tmax and Tmin, respectively). As Tmean is the only variable available in the Pan-European database, we proceeded with the average temperature from the Pan-European data and use Tmax and Tmin from the historical data to obtain the PET of the reference period. Based on this, the result of the average PET for the reference period fits with the historical data, being that the highest values are in the summer months, as expected. Then, PET was obtained for future periods based on the average temperature from forecasts and correcting it with the average temperature from the reference period. This procedure was done using an adapted formula from the mentioned method. Yearly aggregated results can be observed in Figure 6, where it becomes more evident how the average annual PET from different RCMs starts to diverge from the year 2050. 

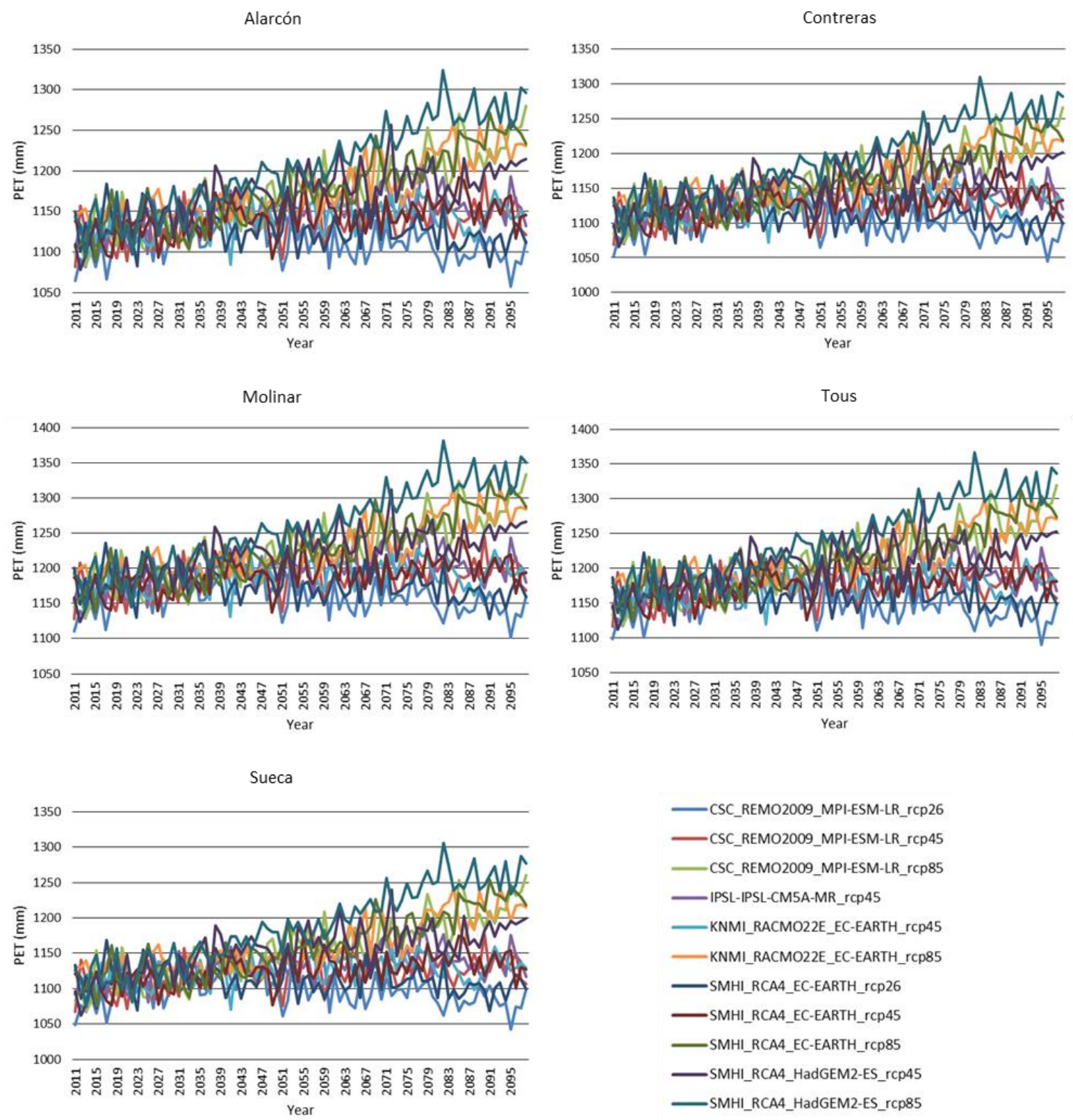

Figure 6. PET for each of the five sub-basins included in the hydrological model

\subsection{Hydrological model results for the future change scenarios}

Once precipitation and PET have been corrected, it is possible to extract streamflows time series from the hydrological model for the future period of interest. The period 2011-2100 was simulated for each one of the 11 RCMs considered, since each model is given by different conditions. Figure 7.a represents the total annual streamflow in the whole basin for all scenarios. As observed, there is a decreasing trend in the streamflows time series. In addition, a large behavioral difference among the scenarios is detected. On the other hand, according to the next planning period, which corresponds with 2021-2027, climate change impacts are evaluated in the 2039 horizon, so in order to study this 
horizon, we consider as a representative period, a margin of ten years before and after 2039. Figure 7.b shows the average annual streamflows for the period 2029-2049. Some results indicate an increase in the average streamflows in the river basin while others show a decrease.

a)

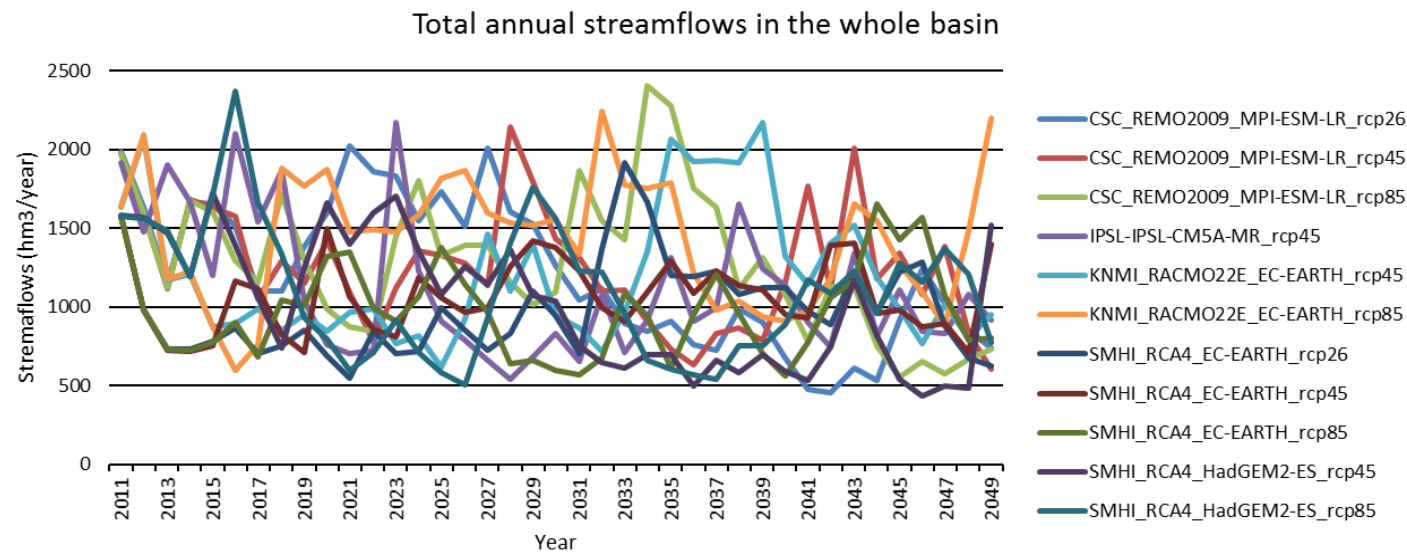

b) Average annual streamflows (2019-2049)

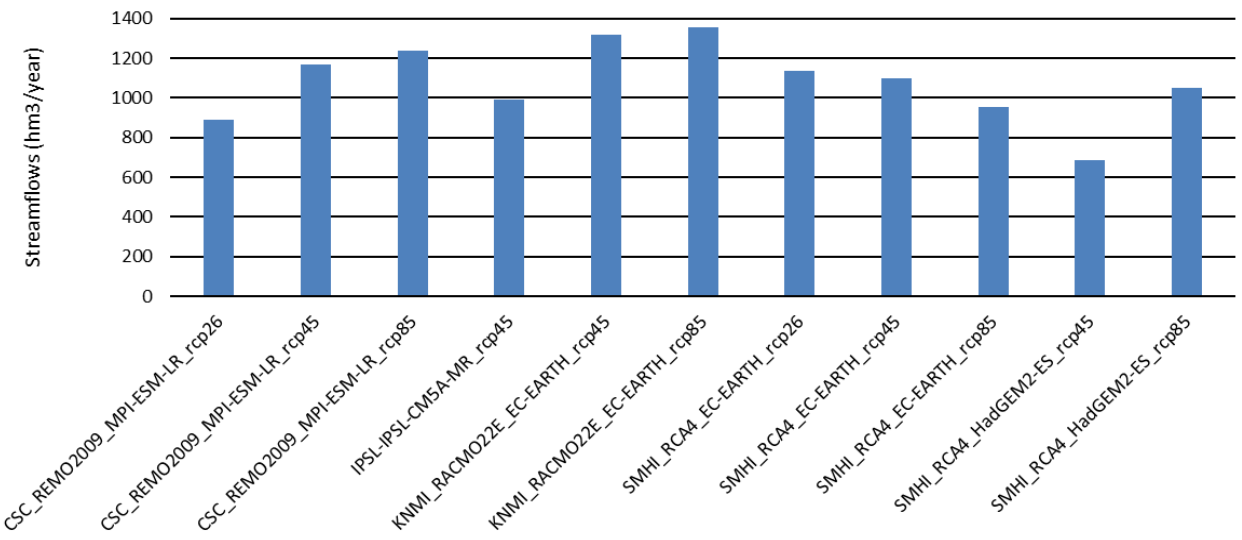

Figure 7. Hydrological model results for the future change scenarios

\subsection{Hydrological projections analysis}

Table 2 presents the basic statistics for the historical series and the adjusted ones. Note that there are several periods to take into account. Firstly, period 1970-2000 coincides with the reference period of Pan-European data. Timeframe 1980-2012 is the one used in river basin management plans for the second planning period (MAGRAMA, 2016). Climate change projections cover the years 2011 to 2100. Finally, climate change impacts are evaluated in the 2039 horizon, and it is defined with the average value from 2029 to 2049.

For the analysis of the water management in the 2039 horizon, the variation in the average values of streamflows in the river basin will be considered. For the rest of the statistical and stochastic properties of the time series of streamflows, it is considered that the values obtained from the 
historical series are maintained. 1,000 streamflow time series were generated with 30 year duration and 4 year warm-up period to avoid dependences with the initial condition.

\begin{tabular}{|c|c|c|c|c|c|}
\hline & $\begin{array}{c}\text { Basic } \\
\text { statistics }\end{array}$ & $\begin{array}{l}\text { Historical series } \\
\text { from reference } \\
\text { period (1971-2000) }\end{array}$ & $\begin{array}{l}\text { Historical series } \\
(1980-2012)\end{array}$ & $\begin{array}{l}\text { Adjusted series } \\
\text { (2011-2100) }\end{array}$ & $\begin{array}{l}\text { Adjusted series } \\
\text { (2029-2049) }\end{array}$ \\
\hline \multirow{4}{*}{ Alarcón } & Average & 342.8 & 286.8 & 182.2 & 131.9 \\
\hline & $\begin{array}{l}\text { Standard } \\
\text { Deviation }\end{array}$ & 174.3 & 140.2 & 121.2 & 66.1 \\
\hline & Bias & 0.7 & 0.7 & 1.4 & 0.7 \\
\hline & $\begin{array}{c}\text { Correlation } \\
\text { coefficient }(r 1)\end{array}$ & 0.4 & 0.21 & 0.44 & 0.41 \\
\hline \multirow{4}{*}{ Contreras } & Average & 312.5 & 253.1 & 194.6 & 159.8 \\
\hline & $\begin{array}{l}\text { Standard } \\
\text { Deviation }\end{array}$ & 160.2 & 136.3 & 95.0 & 84.2 \\
\hline & Bias & 0.5 & 1.0 & 1.7 & 0.7 \\
\hline & $\begin{array}{c}\text { Correlation } \\
\text { coefficient }(\mathrm{r} 1)\end{array}$ & 0.5 & 0.30 & 0.73 & 0.76 \\
\hline \multirow{4}{*}{ Molinar } & Average & 286.7 & 238.9 & 246.3 & 173.1 \\
\hline & $\begin{array}{l}\text { Standard } \\
\text { Deviation }\end{array}$ & 72.9 & 43.8 & 143.1 & 77.5 \\
\hline & Bias & 0.4 & 0.7 & 1.3 & 0.8 \\
\hline & $\begin{array}{c}\text { Correlation } \\
\text { coefficient (r1) }\end{array}$ & 0.9 & 0.55 & 0.56 & 0.47 \\
\hline \multirow{4}{*}{ Tous } & Average & 207.5 & 168.3 & 224.3 & 218.6 \\
\hline & $\begin{array}{l}\text { Standard } \\
\text { Deviation }\end{array}$ & 93.7 & 44.2 & 76.5 & 88.4 \\
\hline & Bias & 1.8 & 0.3 & 0.5 & 0.2 \\
\hline & $\begin{array}{c}\text { Correlation } \\
\text { coefficient }(\mathrm{r} 1)\end{array}$ & 0.8 & 0.36 & 0.70 & 0.54 \\
\hline \multirow{4}{*}{ Sueca } & Average & 232.6 & 241.8 & 196.2 & 136.1 \\
\hline & $\begin{array}{l}\text { Standard } \\
\text { Deviation }\end{array}$ & 122.9 & 115.2 & 81.3 & 43.5 \\
\hline & Bias & 0.7 & 0.7 & 1.2 & 0.6 \\
\hline & $\begin{array}{c}\text { Correlation } \\
\text { coefficient }(\mathrm{r} 1)\end{array}$ & 0.6 & 0.56 & 0.84 & 0.37 \\
\hline
\end{tabular}

As observed, standard deviation is higher in historical period than in adjusted ones. In this sense, the generation of synthetic series is based only on the average values.

\subsection{Analysis of water management scenarios}

This section presents the results obtained from SIMRISK model. The streamflows time series' used are obtained with the stochastic model calibrated for 1980-2012 period. As 1,000 streamflows time series' were generated, now we dispose 1,000 simulations of water management in the river basin. These results will be statistically treated. 
Figure 8 presents the probability of having $10 \%, 20 \%, 30 \%, 40 \%, 50 \%, 60 \%, 70 \%, 80 \%$ and $90 \%$ of the total volume of the addition of the three reservoirs for the average year, as $1,796 \mathrm{hm}^{3}$, is the total capacity of these reservoirs. This scenario considers the current water requirements, which corresponds with the Júcar River Basin Management Plan (RBMP) and amount to 1,083 $\mathrm{hm}^{3}$. As expected, when requirements are higher, it is more likely that reservoirs are empty. Within the average year, as the irrigation season proceeds, which is from April to September, it is more likely that reservoirs are emptied. Note that water requirements are equal or even higher than water resources in the Júcar River Basin.

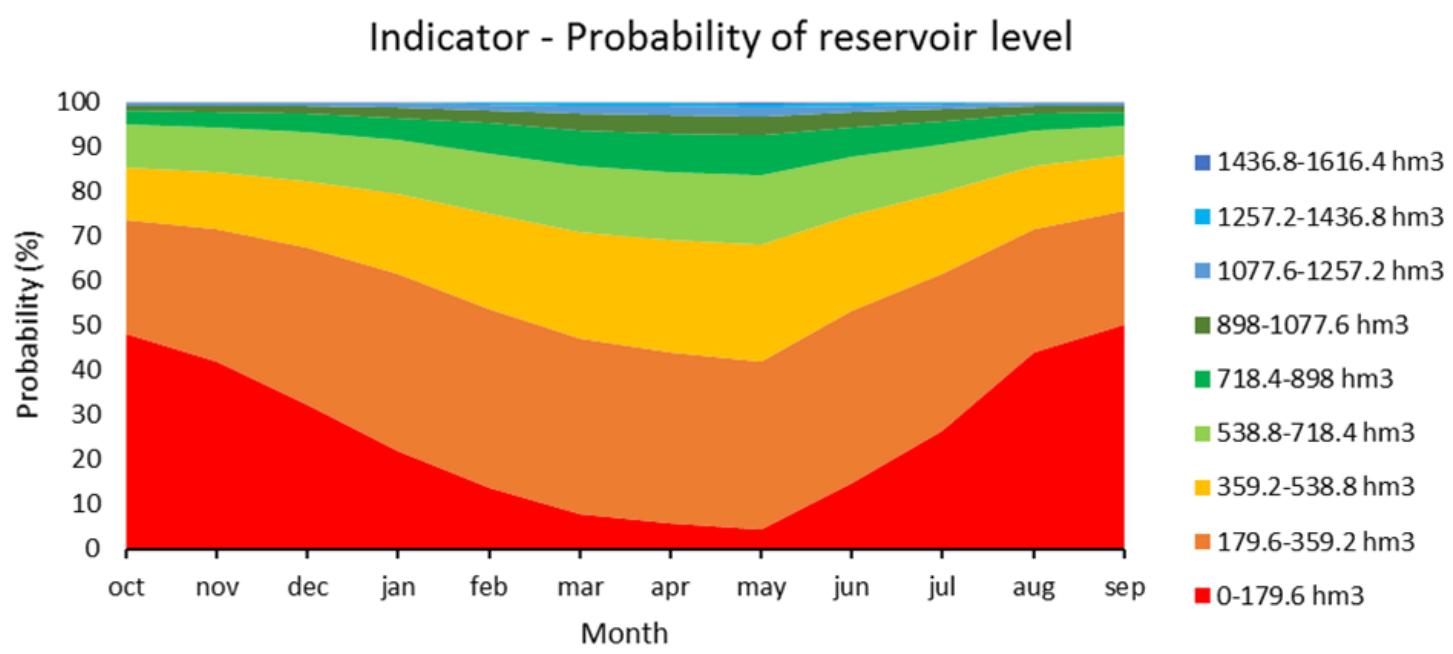

Figure 8. Statistical probabilities of having water resources in each month as a result of the management model, for the current scenario

\subsection{Analysis of future water management scenarios}

Considering climate change projections, Figure 9 presents the probability for the average year that the Alarcón, Contreras and Tous reservoirs are full, the 2039 time horizon for each one of the 11 RCMs is considered in Table 1. This scenario also considers the current water requirements, as section 4.4 does. By the way, some graphics do not reach $100 \%$, this lack of data indicates that the reservoirs are completely full, as the maximum values presented in charts are up to $1,616 \mathrm{hm}^{3}$, and the total capacity reaches $1,796 \mathrm{hm}^{3}$. Regarding to the variations on the groundwater reserves, specifically from the La Mancha Oriental aquifer, these levels follow the tendency of the reliabilities shown in Figure 9. This means that when the probability of having full reservoirs is high, aquifer levels tends to rise, while when this probability is lower, the aquifer tends to have lower levels.

Contrary to what one might expect, in general, results for the 2039 time horizon are much more optimistic than results obtained in previous sections. Further, only one of the eleven RCMs considered present lower levels of water stored in reservoirs than the simulation obtained from 1980-2012, 
where the explanation can be found in Table 2. The Average streamflows obtained in the reference period 1970-2000 are considerably higher than the ones calculated with historical data in the period used in the Júcar RBMP (1980-2012). In this sense, a future horizon has been obtained based on a more optimistic reference period with values of streamflows higher than the historical water resources.

This is a serious discussion, because in Spanish Mediterranean river basins a change in precipitation and temperature patterns occurred at the beginning of the 1980s. This fact is not detected in the reference period of RCM. Then the question about projections of climate change is whether this change refers to the far historical data or it refers to the last 20 years. The point is that in this case study the change has just occurred, and in terms of water resources, it is higher than most of the prognostics obtained in future climate scenarios.

Observing other statistical parameters in future scenarios presented in Table 2, there are some interesting differences that could contribute to the obtained results. The standard deviation and the bias coefficient in inflows to the main reservoirs of the river basin are much smaller in the adjusted series than in the historical period. It implies inflows similar to the average values but not so frequently being less than the average. 
Indicator - Probability of reservoir level depending on RCMs
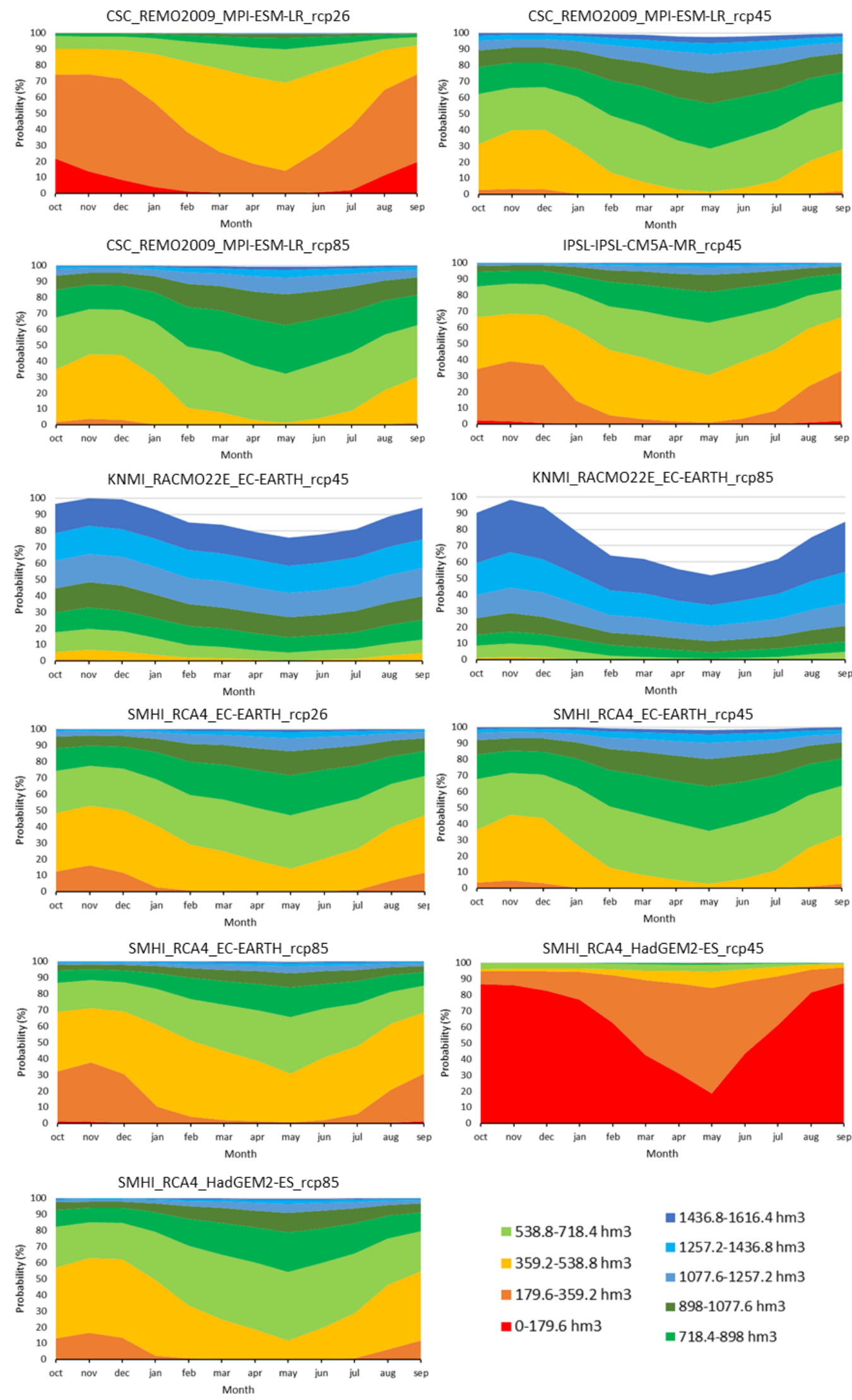

\begin{tabular}{|c|c|}
\hline $538.8-718.4 \mathrm{hm} 3$ & = 1436.8-1616.4 hm3 \\
\hline & $=1257.2-1436.8 \mathrm{hm3}$ \\
\hline מות & $\equiv 1077.6-1257.2 \mathrm{hm3}$ \\
\hline 179.6-359.2 hm3 & = 898-1077.6 hm3 \\
\hline =0-179.6 hm3 & - 718.4-898 hm3 \\
\hline
\end{tabular}

Figure 9. Statistical probabilities of having water resources in each month as a result of the management model, for each RCM 


\section{Discussion}

This study is based on an innovative methodology that combines the use of Pan-European data with hydrological models, stochastic models and multiple simulations of future management focused on water planning. In this field, other works have been conducted with certain nuances. As an example, Haro et al. (2014) analyzes a risk assessment approach within-year operated systems in order to estimate the probability of operative drought in the forthcoming months. So, depending on the risk associated, it would be necessary to anticipate mitigation measures to ensure water supplies for the upcoming irrigation season. Gil et al. (2011) propose a methodology for handling the risk associated with water supply variability in irrigated agriculture by using Monte Carlo simulations of crop production 7 and 3 months before the irrigation season. In the case study analyzed in this paper, the multiple simulations of future management are focused on long-term water planning. In this way, this approach assists water managers and decision makers in the application of strategic measures within future global change. According to Vargas-Amelin and Pindado (2014) in the coming years an increase in supply from non-conventional resources is expected in Spain, such as desalination or wastewater reuse, along with the modernization of irrigation systems. The high costs of these infrastructures and their environmental impacts require a long-term evaluation.

While analyzing each of the steps proposed in the methodology, it is noteworthy to highlight the difficulties encountered for applying the bias correction in streamflows. The comparison performed in section 4.1 was also applied to streamflows from the E-HYPE model and historical data for the reference period of 1971-2000. These were obtained as naturalized river flows, from the same five sub-basins where the main reservoirs are placed (Alarcón, Contreras, Molinar, Tous, Bellús and Sueca). This comparison (Figure 10) allowed us to detect that all scenarios from Pan-European data reached $0 \mathrm{~m}^{3} / \mathrm{s}$ during summer months. The explanation for these results is that the Pan-European hydrological model underestimates the groundwater component of river flows during the dry season. In summer months, the main flows of the Júcar River are due to the discharges from the aquifers, a very important feature for the management of the Júcar Water Exploitation System. In addition, there is an overestimation of inflows in winter months. Thus, with these null values in summer months it was not possible to apply a bias correction. To overcome this inconvenience, it was necessary to resort the use of hydrological models. Thus, the new alternative consisted in doing the same comparison with climate data (precipitation and PET), and then, correcting it and extracting PET to use them in the hydrological model in order to extract streamflows for each sub-basin. This inconvenience is also described in Teutschbein and Seibert (2012), who indicates that although RCMs simulate surface and 
groundwater runoff, these results do not often fit with streamflows observations and therefore they should not be directly used for assessing hydrological impacts at the catchment scale.


Figure 10. Comparison between streamflows from Pan-European and historical data for each of the five sub-basins included in the hydrological model

Actually, according to Donnelly et al. (2016), the results of the E-HYPE model do not completely fit with the observations (E-HYPE) of the Mediterranean areas, being its major weaknesses as the resolution of precipitation patterns, aquifer exchanges, water extractions and regulation. Moreover, it is highlighted that an improvement is needed in areas of southern Europe, like Spain, where there are overestimations of water volume in certain seasons due to the underestimation of irrigation extractions and groundwater recharge (Donnelly et al., 2016). In addition, Andersson et al. (2015) remarked that making simple improvements to input data could result in significant gains in the performance of the model. In this sense, the key factors to improve the performance of the HYPE model in large-scale applications are related to refine the catchment delineation, meteorological input data, and model parameterisation (Andersson et al., 2015).

As noted by Pulido-Velazquez et al. (2011), little interest has been taken to regionalization techniques to assess the impacts of global change on water resources systems in both runoff and groundwater recharge. Being a fact of great importance in conjunctive-use systems, as the Júcar River Basin is. The quality of bias-corrected RCMs is strongly dependent on the selected algorithm, and simulations driven with adjusted RCM variables are best suited to observed values than results forced with unadjusted RCM climate variables (Teutschbein and Seibert, 2012). Nevertheless, we should not 
forget the inconveniences of bias correction. On the one hand, it cannot alleviate the existence of incorrect representations of dynamic and/or physical processes and, on the other hand, it considers that the bias is stationary even in the long term, as noted by (Marcos-Garcia and Pulido-Velazquez, 2017; Teutschbein and Seibert, 2012).

The results provided by the hydrological model create doubts concerning the traditional assessment of climate change in Spanish water planning (MAGRAMA, 2008), which is considered by multiplying the streamflows time series by a reducing factor. This approach presents the advantage of its simplicity preserving the patterns of spatial and temporal variability observed but instead, it does not consider potential changes in the probability distribution of streamflows (Marcos-Garcia and Pulido-Velazquez, 2017). As an example, considering the scenario "CSC_REMO2009_MPI-ESM-LR_rcp26", the average streamflows for the entire river basin in the 2039 time horizon is $887 \mathrm{hm}^{3} /$ year. In this sense, Table 3 shows the relationship between the median values of each time series in each month for the future horizon considered with respect to the historical data in the period 1980-2012. Variations of streamflows by zones are observed. In the headwaters (Alarcón, Contreras and Molinar) the winter streamflows (which are the most important) are reduced, during the summer they remain similar, and in the lower basin they increase considerably. The largest increase occurs in the streamflows downstream to the last regulation reservoir, Sueca, which may imply that these resources are not usable in its entirety. In the case of the Júcar River District, the percentage of decrease in natural streamflows to incorporate the effect of climate change is 9\% (MAGRAMA, 2008). This percentage is in contrast with the results of Table 3, which in the best-case, the reduction amounts to $24 \%$ (Tous streamflows) and, in the worst case, it amounts to 52\% (Alarcón) in comparison with 1980-2012 period.

\begin{tabular}{|c|c|c|c|c|c|}
\cline { 2 - 6 } \multicolumn{1}{c|}{} & Alarcón & Contreras & Mancha & Tous & Sueca \\
\hline oct & 0.91 & 1.40 & 0.72 & 1.14 & 0.91 \\
\hline nov & 0.65 & 1.04 & 0.69 & 0.99 & 0.86 \\
\hline dic & 0.52 & 0.68 & 0.67 & 0.80 & 0.77 \\
\hline ene & 0.38 & 0.52 & 0.56 & 0.66 & 0.63 \\
\hline feb & 0.45 & 0.53 & 0.61 & 0.69 & 0.64 \\
\hline mar & 0.44 & 0.57 & 0.62 & 0.71 & 0.67 \\
\hline abr & 0.34 & 0.46 & 0.50 & 0.60 & 0.59 \\
\hline may & 0.35 & 0.47 & 0.51 & 0.59 & 0.60 \\
\hline jun & 0.43 & 0.55 & 0.55 & 0.67 & 0.68 \\
\hline jul & 0.55 & 0.74 & 0.62 & 0.79 & 0.82 \\
\hline ago & 0.59 & 0.81 & 0.62 & 0.79 & 0.86 \\
\hline sep & 1.02 & 0.94 & 0.77 & 0.93 & 0.85 \\
\hline
\end{tabular}

\begin{tabular}{|c|c|c|c|c|c|}
\cline { 2 - 6 } \multicolumn{1}{c|}{} & Alarcón & Contreras & Mancha & Tous & Sueca \\
\hline $\begin{array}{c}\text { Long historical } \\
\text { series } \\
(1940-2012)\end{array}$ & 396 & 342 & 683 & 1273 & 1500 \\
\hline $\begin{array}{c}\text { Short historical } \\
\text { series } \\
(1980-2012)\end{array}$ & 288 & 253 & 527 & 949 & 1192 \\
\hline $\begin{array}{c}\text { Horizon 2039 } \\
\text { projection }\end{array}$ & 138 & 168 & 320 & 717 & 860 \\
\hline $\begin{array}{c}\text { Future } \\
\text { projection/ } \\
\text { long series }\end{array}$ & $35 \%$ & $49 \%$ & $47 \%$ & $56 \%$ & $57 \%$ \\
\hline $\begin{array}{c}\text { Future } \\
\text { projection/ } \\
\text { short series }\end{array}$ & $48 \%$ & $66 \%$ & $61 \%$ & $76 \%$ & $72 \%$ \\
\hline
\end{tabular}

Table 3. Average streamflows obtained for the 2039 horizon using CSC_REMO2009_MPI-ESM-LR_rCp26 compared with 1980-2012 period

At this point, it is required to highlight that the results of the hydrological model are crucial to simulate the conjunctive-use of water in the case study. In order to estimate the effects of climate change on 
aquifer recharge, other researches have handled this issue by assuming the aquifer recharge to be proportional to the difference between evaporation and precipitation (Pulido-Velazquez et al., 2011). Concerning the results of future management scenarios, different values of streamflows have been considered. Nevertheless, operating rules have been maintained. In this respect, as noted by (MacianSorribes and Pulido-Velazquez, 2017) operating rules support guidance to the system managers, but it is required to adjust them to the conditions. Moreover, there is a relationship between the hydrological state of the system and the type of measure to be applied (Pedro-Monzonís et al., 2015). Therefore, these operating rules will depend on the basin drought status, which future works will be directed towards improving this fact. As far as the model of the system used is concerned, the use of a simulation model aims to explore the performance of the system under the existing operating rules, whereas the use of an optimization model, as proposed by Haro et al. (2014), enables the best feasible management of the system. The latter approach could be the most appropriate in short-term water management, as stated before.

Regarding the results obtained in section 4.4 and 4.5 , there is a chance that climate change that has been predicted for the future has already occurred in the Júcar River Basin. The Júcar Water Exploitation System is characterized by a marked reduction in natural streamflows throughout the past 30 years, clearly showing the existence of two periods (before and after the $80 \mathrm{~s}$ ), in which the difference between their averaged streamflows is close to $500 \mathrm{hm}^{3}$ per year (Pérez-Martín et al., 2013). These changes in the climate are not reflected in the RCM in the geography of the Júcar River Basin. These changes that were not detected could be the reason for the optimistic results, where the average of the total available water resources in the reference period (1971-2000) provided by the EHYPE model is higher than the reality. In this sense, it would be recommendable to divide the reference period into two periods; before and after the 80 s, in order to begin the analysis with more realistic data and to obtain reliable results for decision-making.

As mentioned above, the methodology presented comprises several steps, and each of these steps requires an exhaustive and detailed analysis, since they adds great uncertainties and that the decisions based on them can affect the final results. These uncertainties are introduced by RCMs themselves due to the uncertainty related to future greenhouse gas emissions, the climate system response, or the formulation climate models to produce future scenarios (Kjellström et al., 2016; Teutschbein and Seibert, 2012), and also by the proposed modeling chain, in the hydrological model (Marcos-Garcia and Pulido-Velazquez, 2017), in the stochastic model results and in the water management model itself. In this sense, according to Pulido-Velazquez et al. (2011), the impacts caused by climate change 
and the required adaptation strategies are scenario dependent, or even more, methodological dependent.

It is therefore necessary to appoint that all these processes are framed within the climatic services. Just like the SWICCA platform, there are other climate service prototypes such as the Stadtbaukasten (Cortekar et al., 2016), which is focused on adapting cities to the projected changes on time, or the Swedish climate service (Kjellström et al., 2016), which is centered on RCMs from the Rossby Centre RCM RCA4. In all cases, these climate services are intended to connect climate scientists, decisionmakers and users of climate information in general, to know what is going on with the climate, and how to respond and act on future weather realities (van den Hurk et al., 2016).

Finally, this work has been able to detect some constraints. First of all, the E-HYPE model needs some improvements in order to capture the real features of this Mediterranean area. Also, the bias correction could have been performed with a more accurate method for the case of precipitation and in an easier way for the temperature, if all data had been available to apply the Hargreaves method for obtaining the PET. On the other hand, we must not neglect the limitations of the models (hydrological, stochastic and management) developed in this research as all of them represent a simplification of a complex system, which can lead to the misleading of some important factors. Sometimes, these kinds of studies need to incorporate new points of view and the reformulation of the approach.

\section{Conclusions}

The main objective of this research is to develop, implement and validate a novel approach to link climate services with decision-making in water resources planning and management within climate change and water scarcity. The methodology presented comprises several steps consisting of a hydrological model, a stochastic model and multiple runs of a water management model. Each of these steps requires an exhaustive and detailed analysis, since the decisions considered for them can influence the final results. This uncertainty is added on the one provided by the RCM. One of the main improvements of the proposed approach is its capability for operating with complex systems, as it has been demonstrated in the case study analyzed, providing an overall representation of the state of the system.

We have applied this modeling chain to the Júcar Water Exploitation System. It has demonstrated that contrary to expected, results for the future time horizon 2039 are much more enthusiastic than results obtained in the current situation, as it is built on a more optimistic reference period with values of 
water resources greater than the historical ones. In this sense, results indicate that there is the possibility that climate change expected for the future has already happened in our case study.

Another envisaged alternative is that the RCMs do not work correctly in this area, as they do not contain the important change in the climate patterns that has been registered during the last three decades. In any case, more extensive research is needed in each step of this process. Bias correction could be reformulated in other parameters, and climate models should be revised trying to explain the real change in the climate, which has happened in recent history.

\section{Acknowledgements}

The authors thank the anonymous reviewers for their valuable comments, suggestions and positive feedback. All remaining errors, however, are solely the responsibility of the authors. We would also like to express our gratitude to the Júcar River Basin Authority - Confederación Hidrográfica del Júcar (Spanish Ministry of Agriculture, Fishery, Food and Environment) for providing data to develop this study. The authors wish to thank the Spanish Ministry of Economy and Competitiveness for its financial support through the NUTEGES project (CGL2012-34978) and ERAS project (CTM2016-77804-P). We also value the support provided by the European Community's Seventh Framework Program in financing the projects ENHANCE (FP7-ENV-2012, 308438), AGUAMOD (Interreg V-B Sudoe 2016), SWICCA (ECMRWF-Copernicus-FA 2015/C3S_441-LOT1/SMHI) and IMPREX (H2020-WATER-20142015, 641811).

\section{References}

Andersson, J.C.M., Pechlivanidis, I.G., Gustafsson, D., Donnelly, C., Arheimer, B., 2015. Key factors for improving large-scale hydrological model performance. Eur. Water 49, 77-88.

Andreu, J., Capilla, J., Sanchís, E., 1996. AQUATOOL, a generalized decision-support system for water-resources planning and operational management. J. Hydrol. 177, 269-291. doi:10.1016/0022-1694(95)02963-X

Bates, B.C., Kundzewicz, Z.W., Wu, S., Palutikof, J.P., 2008. Climate Change and Water, Technical Paper of the Intergovernmental Panel on Climate Change. IPCC Secretariat, Geneva. doi:10.1016/j.jmb.2010.08.039

Bergström, S., Forsman, A., 1973. Development of a conceptual deterministic rainfall-runoffmodel. Hydrol. Res. 4. 
Confederación Hidrográfica del Júcar, 2015. Plan Hidrológico de la Demarcación Hidrográfica del Júcar.

Cortekar, J., Bender, S., Brune, M., Groth, M., 2016. Why climate change adaptation in cities needs customised and flexible climate services. Clim. Serv. 4, 42-51. doi:10.1016/j.cliser.2016.11.002

Donnelly, C., Andersson, J.C.M., Arheimer, B., 2016. Using flow signatures and catchment similarities to evaluate the E-HYPE multi-basin model across Europe. Hydrol. Sci. J. 6667, 255-273. doi:10.1080/02626667.2015.1027710

Estrela, T., Pérez-Martín, M.A., Vargas, E., 2012. Impacts of climate change on water resources in Spain. Hydrol. Sci. J. 57, 1154-1167. doi:10.1080/02626667.2012.702213

European Commission, 2015. A European research and innovation Roadmap for Climate Services. Publications Office of the European Union, Luxembourg.

Garrote, L., 2009. Cambio climático: Impactos sobre los recursos hídricos y la disponibilidad del agua, in: Jornadas Sobre Las Repercusiones Del Cambio Climático En La Planificación Y Gestión de Los Recursos Hídricos. Universitat Politècnica de València.

Gil, M., Garrido, A., Gómez-Ramos, A., 2011. Economic analysis of drought risk: An application for irrigated agriculture in Spain. Agric. Water Manag. 98, 823-833. doi:10.1016/j.agwat.2010.12.008

Hargreaves, G.H., Samani, Z.A., 1985. Reference crop evapotranspiration from temperature. Appl. Eng. Agric. 1 (2), 96-99.

Haro, D., Solera, A., Paredes, J., Andreu, J., 2014. Methodology for drought risk assessment in within-year regulated reservoir systems. Application to the Orbigo River system (Spain). Water Resour. Manag. 28, 3801-3814. doi:10.1007/s11269-014-0710-3

Herrera, S., Gutiérrez, J.M., Ancell, R., Pons, M.R., Frías, M.D., Fernández, J., 2012. Development and analysis of a 50-year high-resolution daily gridded precipitation dataset over Spain (Spain02). Int. J. Climatol. 32, 74-85. doi:10.1002/joc.2256

Hundecha, Y., Arheimer, B., Donnelly, C., Pechlivanidis, I., 2016. A regional parameter estimation scheme for a pan-European multi-basin model. J. Hydrol. Reg. Stud. 6, 90111. doi:10.1016/j.ejrh.2016.04.002

IPCC, 2014. Summary for Policymakers, Climate Change 2014: Synthesis Report. Contribution of Working Groups I, II and III to the Fifth Assessment Report of the Intergovernmental Panel on Climate Change. doi:10.1017/CBO9781107415324

Kjellström, E., Bärring, L., Nikulin, G., Nilsson, C., Persson, G., Strandberg, G., 2016. Production and use of regional climate model projections ??? A Swedish perspective on building climate services. Clim. Serv. 2-3, 15-29. doi:10.1016/j.cliser.2016.06.004

Macian-Sorribes, H., Pulido-Velazquez, M., 2017. Integrating Historical Operating Decisions and Expert Criteria into a DSS for the Management of a Multireservoir System. J. Water 
Resour. Plan. Manag. 143. doi:10.1061/(ASCE)WR.1943-5452.0000712

MAGRAMA (Ministerio de Agricultura Alimentación y Medio Ambiente), 2016. Real Decreto 1/2016, de 8 de enero, por el que se aprueba la revisión de los Planes Hidrológicos de las demarcaciones hidrográficas del Cantábrico Occidental, Guadalquivir, Ceuta, Melilla, Segura y Júcar, y de la parte española de las demarcaciones hidrog.

MAGRAMA (Ministerio de Agricultura Alimentación y Medio Ambiente), 2008. Instrucción de Planificación Hidrológica. ORDEN ARM/2656/2008, de 10 de septiembre, por la que se aprueba la instrucción de planificación hidrológica.

Marcos-Garcia, P., Pulido-Velazquez, M., 2017. Cambio climático y planificación hidrológica: ¿es adecuado asumir un porcentaje único de reducción de aportaciones para toda la demarcación? Ing. del agua 21, 35. doi:10.4995/ia.2017.6361

Merino, J.M., 2012. Evaluación del recurso hídrico en la cuenca del río Júcar (España) mediante la aplicación de modelos semiagregados precipitación-escorrentía. Universitat Plitècnica de València.

MMA (Ministerio de Medio Ambiente), 2005. Informe Evaluación Preliminar General de los Impactos en España por Efectos del Cambio Climático.

Paredes-Arquiola, J., Solera, A., Andreu, J., Lerma, N., 2012. Manual técnico de la herramienta EVALHID para la evaluación de recursos hídricos.

Pedro-Monzonís, M., Jiménez-Fernández, P., Solera, A., Jiménez-Gavilán, P., 2016. The use of AQUATOOL DSS applied to the System of Environmental- Economic Accounting for Water ( SEEAW ). J. Hydrol. 533, 1-14. doi:10.1016/j.jhydrol.2015.11.034

Pérez-Martín, M., Thurston, W., Estrela, T., del Amo, P., 2013. Cambio en las series hidrológicas de los últimos 30 años y sus causas. El efecto 80, in: III Jornadas de Ingeniería Del Agua (JIA 2013). La Protección Contra Los Riesgos Hídricos. Valencia, Spain, pp. 527534.

Pulido-Velazquez, D., Garrote, L., Andreu, J., Martin-Carrasco, F.J., Iglesias, A., 2011. A methodology to diagnose the effect of climate change and to identify adaptive strategies to reduce its impacts in conjunctive-use systems at basin scale. J. Hydrol. 405, 110-122. doi:10.1016/j.jhydrol.2011.05.014

Salas, J.D., Delleur, J.W., Yevjevich, V.M., Lane, W.L., 1980. Applied Modeling of Hydrologic Time Series. Water Resour. Publ. Littleton, Color. USA.

Sánchez-Quispe, S., Andreu, J., Solera, A., 2001. Gestión de Recursos Hídricos con Decisiones Basadas en Estimación del Riesgo. Universitat Politècnica de València.

Solera, A., Pedro-Monzonís, M., Andreu, J., Estrela, T., n.d. Analysing hydropower production in stressed river basins within the SEEA-W approach. The Júcar River case. Hydrol. Res.

Teutschbein, C., Seibert, J., 2012. Bias correction of regional climate model simulations for hydrological climate-change impact studies: Review and evaluation of different 
methods. J. Hydrol. 456-457, 12-29. doi:10.1016/j.jhydrol.2012.05.052

van den Hurk, B.J.J.M., Bouwer, L.M., Buontempo, C., D??scher, R., Ercin, E., Hananel, C., Hunink, J.E., Kjellstr??m, E., Klein, B., Manez, M., Pappenberger, F., Pouget, L., Ramos, M.H., Ward, P.J., Weerts, A.H., Wijngaard, J.B., 2016. Improving predictions and management of hydrological extremes through climate services. Clim. Serv. 1, 6-11. doi:10.1016/j.cliser.2016.01.001

van Vliet, M.T.H., Donnelly, C., Strömbäck, L., Capell, R., Ludwig, F., 2015. European scale climate information services for water use sectors. J. Hydrol. 528, 503-513. doi:10.1016/j.jhydrol.2015.06.060

Vargas-Amelin, E., Pindado, P., 2014. The challenge of climate change in Spain: Water resources, agriculture and land. J. Hydrol. 518, 243-249. doi:10.1016/j.jhydrol.2013.11.035 